\title{
Growth of Chrysanthemum Cultivars as Affected by Silicon Source and Application Method
}

\author{
Iyyakkannu Sivanesan', Moon Sook Son ${ }^{2}$, Prabhakaran Soundararajan², and Byoung Ryong Jeong ${ }^{1,2,3 *}$ \\ ${ }^{I}$ Institute of Agriculture and Life Science, Gyeongsang National University, Jinju 660-701, Korea \\ ${ }^{2}$ Department of Horticulture, Division of Applied Life Science (BK21 Program), Graduate School, \\ Gyeongsang National University, Jinju 660-701, Korea \\ ${ }^{3}$ Research Institute of Life Science, Gyeongsang National University, Jinju 660-701, Korea
}

\begin{abstract}
The effect of different silicon ( $\mathrm{Si}$ ) sources and methods of application on the growth of two chrysanthemum cultivars grown in a soilless substrate was investigated. Rooted terminal cuttings of Dendranthema grandiflorum 'Lemmon Eye' and 'Pink Eye' were transplanted into pots containing a coir-based substrate. A nutrient solution containing 0 or $50 \mathrm{mg} \cdot \mathrm{L}^{-1} \mathrm{Si}$ from calcium silicate $\left(\mathrm{CaSiO}_{3}\right)$, potassium silicate $\left(\mathrm{K}_{2} \mathrm{SiO}_{3}\right)$ or sodium silicate $\left(\mathrm{Na}_{2} \mathrm{SiO}_{3}\right)$ was supplied once a day through an ebb-and-flood sub irrigation system. A foliar spray of 0 or $50 \mathrm{mg} \cdot \mathrm{L}^{-1} \mathrm{Si}$ was applied twice a week. Cultivar and application method had a significant effect on plant height. Cultivar, application method, and Si source had a significant effect on plant width. Of the three $\mathrm{Si}$ sources studied, $\mathrm{K}_{2} \mathrm{SiO}_{3}$ was found to be the best for the increasing number of flowers, followed by $\mathrm{CaSiO}_{3}$ and $\mathrm{Na}_{2} \mathrm{SiO}_{3}$. In both the cultivars, sub irrigational supply of Si developed necrotic lesions in the older leaves at the beginning of the flowering stage as compared to the control and foliar spray of Si. Cultivar, application method, Si source, and their interactions had significant influence on leaf tissue concentrations of calcium $(\mathrm{Ca})$, potassium $(\mathrm{K})$, phosphorus $(\mathrm{P})$, magnesium $(\mathrm{Mg})$, sulfur $(\mathrm{S})$, sodium $(\mathrm{Na})$, boron $(\mathrm{B})$, iron $(\mathrm{Fe})$, and zinc $(\mathrm{Zn})$. The addition of Si to the nutrient solution decreased leaf tissue concentrations of $\mathrm{Ca}, \mathrm{Mg}, \mathrm{S}, \mathrm{Na}, \mathrm{B}, \mathrm{Cu}, \mathrm{Fe}$, and $\mathrm{Mn}$ in both cultivars. The greatest $\mathrm{Si}$ concentration in leaf tissue was found in 'Lemmon Eye' $\left(1420 \mu \mathrm{g} \cdot \mathrm{g}^{-1}\right)$ and 'Pink Eye' $\left(1683 \mu \mathrm{g} \cdot \mathrm{g}^{-1}\right)$ when $\mathrm{K}_{2} \mathrm{SiO}_{3}$ was applied through a sub irrigation system and by foliar spray, respectively.
\end{abstract}

Additional key words: Dendranthema grandiflorum, ebb and flow, foliar spray, necrosis, plant nutrition, silicate

\section{Introduction}

Silicon ( $\mathrm{Si}$ ) has not been considered as an essential element for plant growth and development. However, Si deficiency symptoms were observed in cucumber, sugarcane, and tomato (Miyake and Takahashi, 1978, 1983; Wong et al., 1971). These findings have led to an implication of $\mathrm{Si}$ as an essential element for higher plants (Epstein, 1994). The Si is reported to have beneficial effects on growth, development and yield of many plant species, particularly graminaceous plants such as rice, sugarcane, and wheat (Liang et al., 2007). The beneficial effects of silicon are particularly distinct in plants exposed to abiotic or biotic stresses such as drought, frost, metal toxicity, nutrient imbalance, salinity, and diseases. However, these beneficial effects of Si differ among the plant species, mainly due to $\mathrm{Si}$ accumulation in their tissues or organs (Ma and Yamaji, 2006). Although all plants contain $\mathrm{Si}$ in their bodies, $\mathrm{Si}$ concentration of shoots greatly varies with species, ranges from 0.1 to $10.0 \%$ in dry weight (Epstein, 1999). In general, ferns, gymnosperms, and angiosperms accumulated less $\mathrm{Si}$ in their shoots than non-vascular plant species and horsetails (Hodson et al., 2005). The difference in $\mathrm{Si}$ accumulation between species has been attributed to differences in Si uptake by the roots (Ma and Yamaji, 2006).

The Si supplementation to growing medium affects the quality of several floricultural crops (Mattson and Leatherwood,

\footnotetext{
*Corresponding author: brjeong@gnu.ac.kr

※ Received 2 April 2013; Revised 13 June 2013; Accepted 16 June 2013. This research was supported by Technology Development Program for Agriculture and Forestry, Ministry for Food, Agriculture, Forestry and Fisheries, Republic of Korea, Project No 108102-5. Moon Sook Son and Prabhakaran Soundararajan were supported by a scholarship from the BK21 Program, the Ministry of Education, Science and Technology, Korea.

(c) 2013 Korean Society for Horticultural Science
} 
2010). The inclusion of Si to the nutrient solution enhanced flower quality in many ornamental plants (Ehret et al., 2005; Hwang et al., 2005; Kamenidou et al., 2010; Savvas et al., 2002). Moreover, foliar applications of potassium silicate reduce severity of powdery mildew on cucumber, muskmelon, and zucchini squash (Liang et al., 2005; Menzies et al., 1992). Further, Si foliar spray reduces the incidence and severity of bract necrosis in poinsettia (McAvoy and Bible, 1996).

The genus Chrysanthemum (Asteraceae) comprises about 40 species which are native to Asia and northeastern Europe. Chrysanthemum is one of the most important ornamental crops worldwide and is produced as cut flowers and pot plants. The Si nutrition enhances growth (Moon et al., 2008; Sivanesan et al., 2013) and increases the ability of chrysanthemum to withstand attack by leafminers (Jeong et al., 2012; Parrella et al., 2007). However, Sivanesan et al. (2013) reported that the number and size of chrysanthemum flowers were promoted when the nutrient solution was supplemented with $\mathrm{Si}$, but necrotic lesions developed in adult leaves. Silicon accumulation in natural systems is rarely linked to adverse effects in plants, even in those that have a high Si uptake capacity (Cooke and Leishman, 2011). Montpetit et al. (2012) also reported that the $\mathrm{Si}$ absorption caused leaf necrosis in Arabidopsis and this symptom was proportional to the external Si concentration. Further, they assumed that this symptom was caused by improper regulation of $\mathrm{Si}$ uptake or transport in Arabidopsis transformants. Thus, in this study we investigated the effect of Si sources and methods of application on the growth and development of two chrysanthemum cultivars.

\section{Materials and Methods}

Terminal cuttings of Dendranthema grandiflorum 'Lemmon Eye' and 'Pink Eye' were taken from stock plants grown in a greenhouse. For rooting, the cuttings were planted in a coir-based substrate (Tosilee Medium, Shinan Grow Co., Korea) and kept on a mist (10 s every $10 \mathrm{~min})$ propagation bed with a mean air temperature of $25^{\circ} \mathrm{C}$ and $80 \%$ relative humidity $(\mathrm{RH})$. Rooted cuttings were transplanted into 10 $\mathrm{cm}(370 \mathrm{~mL})$ plastic pots containing a coir-based substrate and a nutrient solution containing 0 or $50 \mathrm{mg} \cdot \mathrm{L}^{-1} \mathrm{Si}$ from calcium silicate $\left(\mathrm{CaSiO}_{3}\right)$, potassium silicate $\left(\mathrm{K}_{2} \mathrm{SiO}_{3}\right)$ or sodium silicate $\left(\mathrm{Na}_{2} \mathrm{SiO}_{3}\right)$ was supplied once a day through a subirrigation system $(1.0 \mathrm{~m} \times 2.0 \mathrm{~m}$ ebb-and-flood bench). A foliar spray of 0 or $50 \mathrm{mg} \cdot \mathrm{L}^{-1} \mathrm{Si}$ was applied twice a week. Additional calcium and potassium introduced by $\mathrm{CaSiO}_{3}$ and $\mathrm{K}_{2} \mathrm{SiO}_{3}$ were subtracted from calcium and potassium nitrate and the loss of nitrate was subsequently reintegrated by addition of nitric acid to formulate all nutrient solutions to have the same essential elements. The composition of the nutrient solution was $\left(\mathrm{mg} \cdot \mathrm{L}^{-1}\right): 708 \mathrm{Ca}\left(\mathrm{NO}_{3}\right)_{2} \cdot 4 \mathrm{H}_{2} \mathrm{O}, 246$ $\mathrm{MgSO}_{4} \cdot 7 \mathrm{H}_{2} \mathrm{O}, 505 \mathrm{KNO}_{3}, 230 \mathrm{NH}_{4} \mathrm{H}_{2} \mathrm{PO}_{4}, 1.24 \mathrm{H}_{3} \mathrm{BO}_{3}$, $0.124 \mathrm{CuSO}_{4} \cdot 5 \mathrm{H}_{2} \mathrm{O}, 4$ Fe-EDTA, $2.2 \mathrm{MnSO}_{4} \cdot 4 \mathrm{H}_{2} \mathrm{O}, 0.08$ $\mathrm{H}_{2} \mathrm{MoO}_{4}$, and $1.15 \mathrm{ZnSO}_{4} \cdot 7 \mathrm{H}_{2} \mathrm{O}$. Plants were grown in a Venlo-type glasshouse under a normal day-light condition with night/day set temperatures of $19 / 27^{\circ} \mathrm{C}$ and $60-70 \% \mathrm{RH}$. Each treatment was consisted of three replicates and each replicate contained 45 plants in an ebb-and-flood bench.

After two weeks, the plants were pinched leaving five nodes. Plant height, stem diameter, number of branches, chlorophyll content, number of flowers, flower diameter, root length, and fresh and dry weights of shoot and root were recorded after 63 days of cultivation. Chlorophyll content was measured on young leaves with a chlorophyll meter (SPAD-502, Konica Minolata Sensing, Inc., Japan). Three measurements per leaf were taken and averaged to obtain a representative chlorophyll concentration value. Dry weight was measured after $72 \mathrm{~h}$ of drying at $70^{\circ} \mathrm{C}$ in a dry oven. For each treatment 45 plants were used for growth analysis.

Dried leaf samples were ground with a stainless mill (Cytclotec, Model 1093, Tector, Hoganas, Sweden) and used for chemical analysis. For each treatment five samples were taken. Ground leaf sample $(1.0 \mathrm{~g})$ in a porcelain crucible was ashed in a Nabertherm muffle furnace (Model LV 5/11/B180, Lilienthal, Bremen, Germany) for $4 \mathrm{~h}$ at $525^{\circ} \mathrm{C}$. The ash was dissolved in $5 \mathrm{~mL} 25 \% \mathrm{HCl}$ solution, followed by $20 \mathrm{~mL}$ of hot $\mathrm{DH}_{2} \mathrm{O}$, and brought to $100 \mathrm{~mL}$ with deionized water. Calcium $(\mathrm{Ca})$, magnesium $(\mathrm{Mg})$, potassium $(\mathrm{K})$, phosphorus $(\mathrm{P})$, sulfur $(\mathrm{S})$, boron $(\mathrm{B})$, copper $(\mathrm{Cu})$, iron $(\mathrm{Fe})$, manganese $(\mathrm{Mn})$, and zinc $(\mathrm{Zn})$ in leaf samples were measured by using an inductively coupled plasma (ICP) spectrometer (Optima 4300DV/5300DV, Perkin Elmer, Germany). Leaf tissue Si concentration was determined according to Sivanesan et al. (2010).

Data collected were analyzed for statistical significance by the SAS (Statistical Analysis System, V. 9.1, Cary, NC, USA) program. The experimental results were submitted to an analysis of variance (F test) and Duncan's multiple range tests $(P \leq 0.05)$.

\section{Results and Discussion}

Cultivar and application method had a significant effect on the plant height, but not by $\mathrm{Si}$ source. Sub irrigational supply of $\mathrm{K}_{2} \mathrm{SiO}_{3}$ and foliar spray of $\mathrm{Na}_{2} \mathrm{SiO}_{3}$ increased plant height of 'Lemmon Eye' $(22.0 \mathrm{~cm})$ and 'Pink Eye' $(30.0 \mathrm{~cm})$, respectively, compared with the control (Table 1). However, sub irrigational supply of $\mathrm{CaSiO}_{3}$ reduced plant height of 'Pink Eye' compared to the control and other treatments. Cultivar, application method, and Si source had a significant 


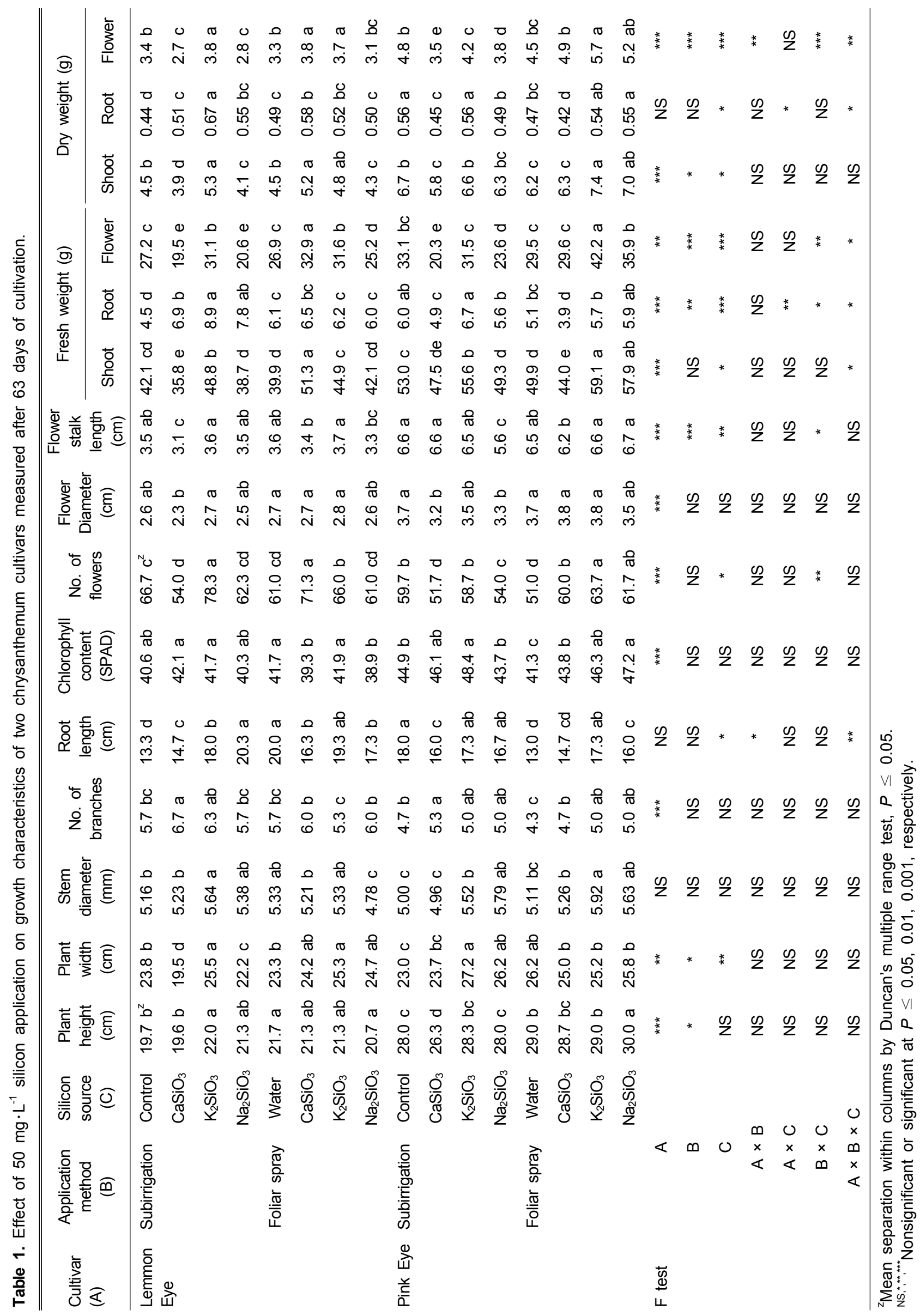


effect on plant width. Of the three $\mathrm{Si}$ sources tested, $\mathrm{K}_{2} \mathrm{SiO}_{3}$ significantly increased plant width in 'Lemmon Eye' (25.5 $\mathrm{cm})$ and 'Pink Eye' $(27.2 \mathrm{~cm})$ when supplied through the sub irrigation system. In 'Lemmon Eye', foliar spray or subirrigational supply of $\mathrm{CaSiO}_{3}$ and $\mathrm{Na}_{2} \mathrm{SiO}_{3}$ increased or reduced plant width, respectively, compared with the control.

No significant difference in the stem diameter was observed in all treatments; however, Si treatment either increased or reduced stem diameter as compared with the control. In 'Lemmon Eye', sub irrigational supply of $\mathrm{K}_{2} \mathrm{SiO}_{3}$ increased stem diameter $(5.64 \mathrm{~mm})$, but reduced when $\mathrm{Na}_{2} \mathrm{SiO}_{3}$ was sprayed $(4.78 \mathrm{~mm})$ as compared with the control. On the other hand both foliar and subirrigational application of $\mathrm{Na}_{2} \mathrm{SiO}_{3}$ increased stem diameter of 'Pink Eye' (Table 1). Similarly, the $\mathrm{Si}$ treatment increased stem diameter in carnation (Bae et al., 2010), chrysanthemum (Moon et al., 2008), gerbera (Savvas et al., 2002), marigold (Sivanesan et al., 2010), rose (Hwang et al., 2005), and zinnia (Kamenidou et al., 2009). Significant difference in number of branches was found between the two cultivars. In both cultivars, subirrigational supply of $\mathrm{CaSiO}_{3}$ increased number of branches as compared to the control and other treatments. A similar result has been reported in chrysanthemum 'Backwang' (Moon et al., 2008). The interaction of cultivar, application method and $\mathrm{Si}$ source had a significant effect on measured root length $(P \leq 0.01)$. The Si nutrition increased root length of chrysanthemum 'Pink Pixe Time', 'Gaya Pink', and 'Lemmon Tree', but limited root length of 'White Angel' (Moon et al., 2008; Sivanesan et al., 2013). Similarly, in this study, Si treatment increased root length of 'Lemmon Eye', while it reduced that of 'Pink Eye' (Table 1). Significant variation in chlorophyll content was observed between the two cultivars. The subirrigational supply of $\mathrm{CaSiO}_{3}$ and $\mathrm{K}_{2} \mathrm{SiO}_{3}$ increased chlorophyll content of 'Lemmon Eye' and 'Pink Eye', respectively, compared with the control. Foliar application of $\mathrm{Na}_{2} \mathrm{SiO}_{3}$ decreased chlorophyll content of 'Lemmon Eye', while it increased that of 'Pink Eye' as compared with the control. These results suggest that the application method had influence on chlorophyll content of chrysanthemum cultivars.

Cultivar and Si source had a significant effect on the number of flowers. Also the interaction of application method and $\mathrm{Si}$ source had a significant influence on number of flowers $(P \leq 0.01)$. Of the three $\mathrm{Si}$ sources studied, $\mathrm{K}_{2} \mathrm{SiO}_{3}$ was found to be the best for increasing number of flowers, followed by $\mathrm{CaSiO}_{3}$ and $\mathrm{Na}_{2} \mathrm{SiO}_{3}$ (Table 1). The sub irrigational and foliar application of $\mathrm{K}_{2} \mathrm{SiO}_{3}$ significantly increased the number of flowers in 'Lemmon Eye' (78.3) and 'Pink Eye' (63.7), respectively (Fig. 1), compared with the control. Flower diameter was also significantly affected by cultivar $(P \leq 0.001)$. The application method and Si source on flower diameter was nonsignificant. Cultivar, application method, and $\mathrm{Si}$ source had a significant effect on length of flower stalk ( $P \leq 0.01)$. The interaction of application method and Si source also had a significant influence on length of flower stalk $(P \leq 0.05)$. The subirrigational and foliar application of $\mathrm{CaSiO}_{3}$ limited flower stalk length of 'Lemmon Eye' (3.1 $\mathrm{cm})$ and 'Pink Eye' $(6.2 \mathrm{~cm})$, respectively (Table 1), compared with the control. Foliar spray of $\mathrm{K}_{2} \mathrm{SiO}_{3}$ and $\mathrm{Na}_{2} \mathrm{SiO}_{3}$ increased length of flower stalk in 'Lemmon Eye' $(3.7 \mathrm{~cm})$ and 'Pink Eye' $(6.7 \mathrm{~cm})$, respectively, compared with the control. Similar results have also been observed in other ornamental plant species such as fuchsia, gerbera, petunia, torenia, and zinnia (Kamenidou et al., 2008, 2010; Mattson and Leatherwood, 2010).

The interaction of cultivar, application method and $\mathrm{Si}$ source had a significant effect on fresh weight of shoot, root, and
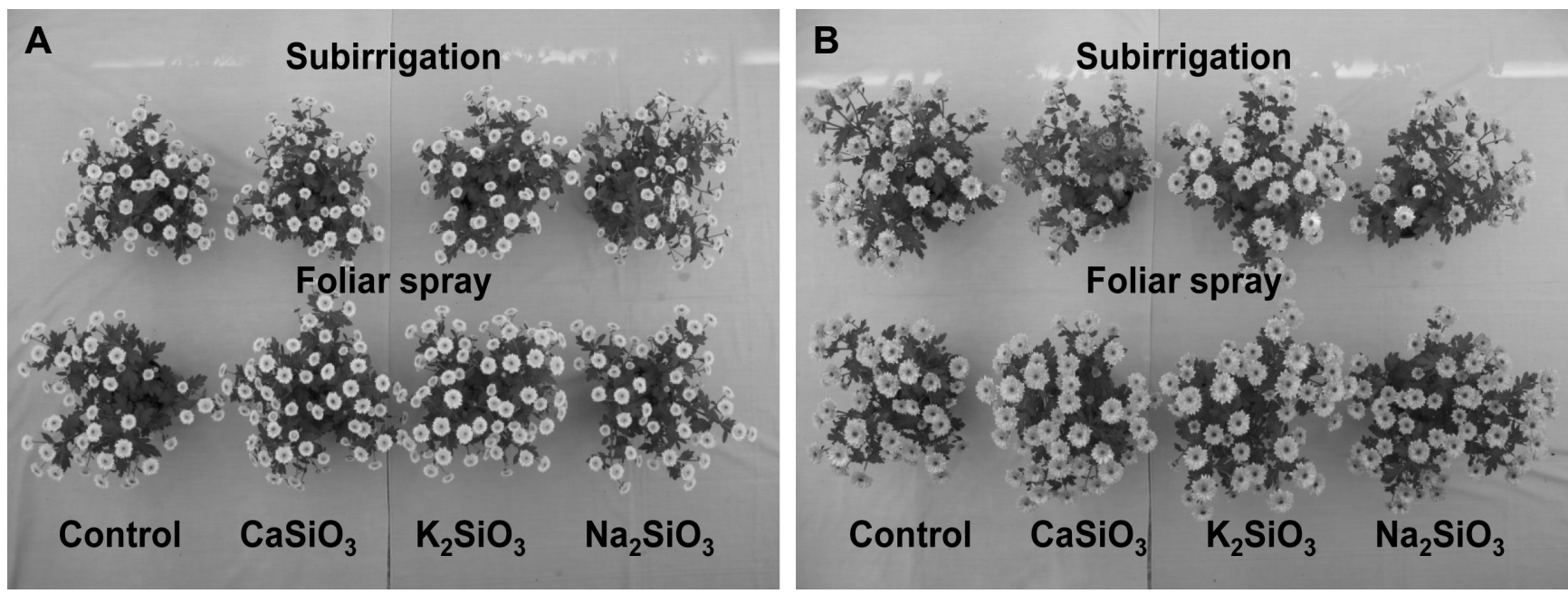

Fig. 1. Effect of foliar or subirrigational application of $50 \mathrm{mg} \cdot \mathrm{L}^{-1}$ silicon on the growth of chrysanthemum 'Lemmon Eye' (A) and 'Pink Eye' (B) after 63 days of cultivation. 
flower (Table 1). Among the two methods of Si application, foliar spray increased fresh weight of shoot significantly in both cultivars. Shoot fresh weight was significantly $(P \leq$ 0.05) greater in 'Lemmon Eye' (51.3 g) and 'Pink Eye' (59.1 g) with the foliar spray of $\mathrm{CaSiO}_{3}$ and $\mathrm{K}_{2} \mathrm{SiO}_{3}$, respectively. In both cultivars, subirrigational supply of $\mathrm{K}_{2} \mathrm{SiO}_{3}$ significantly increased root fresh weight $(P \leq 0.01)$ as compared with the control and other treatments. Flower fresh weight was also significantly $(P \leq 0.001)$ greater in 'Lemmon Eye' (32.9 g) and 'Pink Eye' (42.2 g) with the foliar spray of $\mathrm{CaSiO}_{3}$ and $\mathrm{K}_{2} \mathrm{SiO}_{3}$, respectively. The $\mathrm{Si}$ source had a significant $(P \leq 0.01)$ effect on dry weight of shoot, root, and flower. The greatest shoot dry weight was obtained in 'Lemmon Eye' (5.3 g) and 'Pink Eye' (7.4 g) with subirrigational and foliar application of $\mathrm{K}_{2} \mathrm{SiO}_{3}$, respectively. The application of Si significantly increased or decreased root dry weight of 'Lemmon Eye' (0.67 g) and 'Pink Eye' (0.42), respectively, compared with the control. Cultivar, application method, Si source, and their interactions had a significant effect on flower dry weight (Table 1). Flower dry weight significantly ( $P \leq 0.01$ ) increased in 'Lemmon Eye' with supplied $\mathrm{Si}$ sources except $\mathrm{Na}_{2} \mathrm{SiO}_{3}$. In 'Pink Eye' flower dry weight significantly $(P \leq 0.001)$ increased and decreased with foliar and subirrigational supply of $\mathrm{Si}$, respectively. In both cultivars, subirrigational supply of $\mathrm{Si}$ developed necrotic lesions in the older leaves at the beginning of the flowering as compared with the control and foliar spray of Si. Similar result has been observed in chrysanthemum 'Gaya Pink', 'Lemmon Tree', and 'White Angel' (Sivanesan et al., 2013). The application of Si has been reported to affect the plant tissue element concentrations in several crop species. Cultivar, application method, silicon source, and their interactions had a significant effect on leaf tissue concentrations of $\mathrm{Ca}(P$ $\leq 0.01), \mathrm{K}(P \leq 0.01), \mathrm{P}(P \leq 0.05), \mathrm{Mg}(P \leq 0.05), \mathrm{S}$ $(P \leq 0.05)$, and Na $(P \leq 0.001)$ (Table 2$)$. Leaf tissue $\mathrm{Ca}$ concentration $(P \leq 0.001)$ was significantly differed between the cultivars ('Lemmon Eye' $18.7 \mathrm{mg} \cdot \mathrm{g}^{-1}$ and 'Pink Eye' 10.0 $\left.\mathrm{mg} \cdot \mathrm{g}^{-1}\right)$. Similar result was also reported in chrysanthemum 'Gaya Pink' (14.6 mg $\left.\cdot \mathrm{g}^{-1}\right)$, 'Lemmon Tree' $\left(11.8 \mathrm{mg} \cdot \mathrm{g}^{-1}\right)$, and 'White Angel' (10.4 $\left.\mathrm{mg} \cdot \mathrm{g}^{-1}\right)$ (Sivanesan et al., 2013).

Table 2. Concentrations of $\mathrm{Ca}, \mathrm{K}, \mathrm{P}, \mathrm{Mg}, \mathrm{S}$, and $\mathrm{Na}$ in leaf tissue of two chrysanthemum cultivars as affected by $\mathrm{Si}$ application.

\begin{tabular}{|c|c|c|c|c|c|c|c|c|}
\hline \multirow{2}{*}{ Cultivar (A) } & \multirow{2}{*}{ Application method (B) } & \multirow{2}{*}{ Silicon source $(\mathrm{C})$} & \multicolumn{6}{|c|}{ Concentration $\left(\mathrm{mg} \cdot \mathrm{g}^{-1}\right.$ dry wt.) } \\
\hline & & & $\mathrm{Ca}$ & $\mathrm{K}$ & $\mathrm{P}$ & $\mathrm{Mg}$ & S & $\mathrm{Na}$ \\
\hline \multirow[t]{8}{*}{ Lemmon Eye } & Subirrigation & Control & $18.7 \mathrm{a}^{\mathrm{z}}$ & $57.2 a b$ & $15.2 a b$ & $4.5 \mathrm{a}$ & $2.3 \mathrm{a}$ & $2.96 a$ \\
\hline & & $\mathrm{CaSiO}_{3}$ & $18.4 a b$ & 57.7 a & 15.3 a & $4.2 \mathrm{~b}$ & $2.0 \mathrm{bc}$ & $1.33 \mathrm{~d}$ \\
\hline & & $\mathrm{K}_{2} \mathrm{SiO}_{3}$ & $17.3 \mathrm{c}$ & $57.5 a b$ & $14.0 \mathrm{c}$ & $4.1 \mathrm{c}$ & $1.9 \mathrm{c}$ & $1.75 \mathrm{~b}$ \\
\hline & & $\mathrm{Na}_{2} \mathrm{SiO}_{3}$ & $18.5 a b$ & $56.7 \mathrm{~b}$ & $14.5 \mathrm{~b}$ & $4.1 \mathrm{c}$ & $1.9 \mathrm{c}$ & $1.57 \mathrm{c}$ \\
\hline & Foliar spray & Water & $18.4 a b$ & 57.9 a & $14.5 \mathrm{~b}$ & $4.5 \mathrm{a}$ & $2.1 \mathrm{~b}$ & $0.99 \mathrm{f}$ \\
\hline & & $\mathrm{CaSiO}_{3}$ & 18.7 a & 56.2 bc & $15.4 \mathrm{a}$ & $4.4 \mathrm{a}$ & $2.1 \mathrm{~b}$ & $1.25 \mathrm{de}$ \\
\hline & & $\mathrm{K}_{2} \mathrm{SiO}_{3}$ & $17.9 \mathrm{~b}$ & $55.4 \mathrm{c}$ & $14.0 \mathrm{c}$ & $4.4 \mathrm{a}$ & $2.0 \mathrm{bc}$ & $1.16 \mathrm{e}$ \\
\hline & & $\mathrm{Na}_{2} \mathrm{SiO}_{3}$ & $17.3 \mathrm{c}$ & $56.7 \mathrm{~b}$ & $14.1 \mathrm{bc}$ & $4.2 \mathrm{~b}$ & $2.3 \mathrm{a}$ & $1.65 \mathrm{bc}$ \\
\hline \multirow[t]{8}{*}{ Pink Eye } & Subirrigation & Control & $10.0 \mathrm{bc}$ & $65.7 \mathrm{bc}$ & $7.6 \mathrm{~b}$ & $2.4 \mathrm{c}$ & $2.9 \mathrm{a}$ & $0.73 \mathrm{c}$ \\
\hline & & $\mathrm{CaSiO}_{3}$ & $9.2 \mathrm{c}$ & $67.3 \mathrm{~b}$ & $6.6 \mathrm{~cd}$ & $2.3 \mathrm{~cd}$ & $2.5 \mathrm{c}$ & $0.62 \mathrm{e}$ \\
\hline & & $\mathrm{K}_{2} \mathrm{SiO}_{3}$ & $9.1 \mathrm{c}$ & 70.8 a & $7.0 \mathrm{c}$ & $2.1 \mathrm{~d}$ & $2.7 \mathrm{~b}$ & $0.68 \mathrm{~d}$ \\
\hline & & $\mathrm{Na}_{2} \mathrm{SiO}_{3}$ & $9.2 \mathrm{c}$ & $70.2 \mathrm{a}$ & $6.5 \mathrm{~d}$ & $2.2 \mathrm{~cd}$ & $2.6 \mathrm{bc}$ & $0.67 \mathrm{~d}$ \\
\hline & Foliar spray & Water & $10.4 \mathrm{~b}$ & $63.4 \mathrm{c}$ & $6.8 \mathrm{c}$ & $3.1 \mathrm{ab}$ & $2.6 \mathrm{bc}$ & $0.79 \mathrm{~b}$ \\
\hline & & $\mathrm{CaSiO}_{3}$ & $10.9 a$ & $67.8 \mathrm{~b}$ & $8.4 \mathrm{a}$ & $2.9 \mathrm{~b}$ & $3.0 \mathrm{a}$ & $0.85 a$ \\
\hline & & $\mathrm{K}_{2} \mathrm{SiO}_{3}$ & $10.9 a$ & $60.8 \mathrm{~d}$ & $7.7 \mathrm{~b}$ & $3.2 \mathrm{a}$ & $2.7 \mathrm{~b}$ & $0.85 a$ \\
\hline & & $\mathrm{Na}_{2} \mathrm{SiO}_{3}$ & $10.1 \mathrm{bc}$ & $65.9 \mathrm{bc}$ & $7.3 \mathrm{bc}$ & $2.5 \mathrm{c}$ & $2.9 a b$ & $0.73 \mathrm{c}$ \\
\hline \multirow[t]{7}{*}{$\mathrm{F}$ test } & $A$ & & $* * *$ & $* * *$ & $* * *$ & $* * *$ & $* * *$ & $* * *$ \\
\hline & B & & $* * *$ & $* * *$ & * & $* * *$ & $* * *$ & $* * *$ \\
\hline & C & & $* * *$ & * & $* * *$ & $* * *$ & $* *$ & $* * *$ \\
\hline & $A \times B$ & & $* * *$ & $* \star *$ & $* \star *$ & $* * *$ & NS & $* * *$ \\
\hline & $A \times C$ & & $* *$ & $* *$ & $* *$ & NS & NS & $* * *$ \\
\hline & $B \times C$ & & $* * *$ & $* * *$ & $* * *$ & $* * *$ & $* * *$ & $* * *$ \\
\hline & $A \times B \times$ & $\mathrm{C}$ & $* *$ & $* *$ & * & * & * & $* * *$ \\
\hline
\end{tabular}

${ }^{\mathrm{z}}$ Mean separation within columns by Duncan's multiple range test, $P \leq 0.05$.

NS, ${ }^{* * * *, * * *}$ Nonsignificant or significant at $P \leq 0.05,0.01,0.001$, respectively. 
In 'Lemmon Eye' subirrigational supply of $\mathrm{K}_{2} \mathrm{SiO}_{3}$ or foliar spray of $\mathrm{Na}_{2} \mathrm{SiO}_{3}$ decreased leaf tissue concentration of $\mathrm{Ca}$ compared with the control. In 'Pink Eye' leaf Ca concentration increased and decreased with the foliar and sub irrigational application of $\mathrm{Si}$, respectively. In chrysanthemum $\mathrm{Si}$ nutrition increased leaf tissue $\mathrm{Ca}$ concentration in 'Gaya pink' and 'Lemmon Tree' but that was unaffected in 'White Angel' (Sivanesan et al., 2013). Wang and Han (2007) reported that the Si supplementation did not affect leaf tissue $\mathrm{Ca}$ concentration in alfalfa. In contrast $\mathrm{Si}$ treatment reduced leaf tissue $\mathrm{Ca}$ concentration in sunflower (Kamenidou et al., 2008). The subirrigational supply of $\mathrm{Na}_{2} \mathrm{SiO}_{3}$ and $\mathrm{Si}$ foliar applications decreased leaf tissue $\mathrm{K}$ concentration in 'Lemmon Eye'. However, sub irrigational supply of Si significantly increased the leaf K content in 'Pink Eye'. Surprisingly in both cultivars, leaf tissue $\mathrm{K}$ concentration decreased with foliar spray of $\mathrm{K}_{2} \mathrm{SiO}_{3}$ as compared with control (Table 2). The inclusion of $\mathrm{Si}$ along with other nutrients in the nutrient solution decreased the $\mathrm{K}$ uptake of rice plants (Islam and Saha, 1969). In contrast, K uptake by solution-cultured barley plants increased following Si applications (Liang et al., 1996). In this study, leaf tissue $\mathrm{K}$ concentration in chrysanthemum cultivars increased and decreased depending upon the $\mathrm{Si}$ source applied. In 'Lemmon Eye', P concentration of leaf tissue slightly increased with application of $\mathrm{CaSiO}_{3}$, but it decreased significantly with application of $\mathrm{K}_{2} \mathrm{SiO}_{3}$ or $\mathrm{Na}_{2} \mathrm{SiO}_{3}$, as compared with the control. Root or foliar application of $\mathrm{CaSiO}_{3}$ significantly decreased or increased leaf tissue $\mathrm{P}$ concentration of 'Pink Eye'. Thus, applied Si sources either increased or decreased $\mathrm{P}$ concentration in chrysanthemum cultivars. The Si treatment tends to increase the $\mathrm{P}$ concentration in the green tops of sugarcane (Roy et al., 1971), but decreased in rice (Guo et al., 2005; Ma and Takahashi, 1990). In both cultivars subirrigational supply of $\mathrm{Si}$ decreased leaf tissue $\mathrm{Mg}$ concentration, while foliar Si spray decreased and increased leaf $\mathrm{Mg}$ concentration of 'Lemmon Eye' and 'Pink Eye', respectively, compared with the control. The inclusion $\mathrm{Si}$ to the nutrient solution decreased leaf tissue $\mathrm{S}$ concentrations in both cultivars. The $\mathrm{Na}$ concentration in the shoots of barley and rice decreased with addition of Si (Liang et al., 2007).

Table 3. Concentrations of $\mathrm{B}, \mathrm{Cu}, \mathrm{Fe}, \mathrm{Mn}, \mathrm{Zn}$, and $\mathrm{Si}$ in leaf tissue of two chrysanthemum cultivars as affected by Si application.

\begin{tabular}{|c|c|c|c|c|c|c|c|c|}
\hline \multirow{2}{*}{ Cultivar (A) } & \multirow{2}{*}{ Application method (B) } & \multirow{2}{*}{ Silicon source $(\mathrm{C})$} & \multicolumn{6}{|c|}{ Concentration $\left(\mu \mathrm{g} \cdot \mathrm{g}^{-1}\right.$ dry wt.) } \\
\hline & & & B & $\mathrm{Cu}$ & $\mathrm{Fe}$ & $\mathrm{Mn}$ & $\mathrm{Zn}$ & Si \\
\hline \multirow[t]{8}{*}{ Lemmon Eye } & Subirrigation & Control & $28.8 a^{z}$ & $9.2 \mathrm{~b}$ & $110 a$ & 221 a & $80 \mathrm{~g}$ & $885 d$ \\
\hline & & $\mathrm{CaSiO}_{3}$ & $22.7 \mathrm{~d}$ & $6.9 \mathrm{~d}$ & $84 d$ & 166 ef & $83 \mathrm{gf}$ & $1,109 \mathrm{bc}$ \\
\hline & & $\mathrm{K}_{2} \mathrm{SiO}_{3}$ & $27.8 a b$ & $8.6 \mathrm{bc}$ & $91 \mathrm{c}$ & $212 b$ & $134 a$ & 1,420 a \\
\hline & & $\mathrm{Na}_{2} \mathrm{SiO}_{3}$ & $25.5 \mathrm{bc}$ & $7.4 \mathrm{~cd}$ & $90 \mathrm{c}$ & $186 \mathrm{~d}$ & $88 \mathrm{f}$ & $1,139 \mathrm{bc}$ \\
\hline & Foliar spray & Water & $23.9 \mathrm{~cd}$ & $7.9 \mathrm{c}$ & $102 \mathrm{~b}$ & $202 c$ & $125 d$ & $791 \mathrm{~d}$ \\
\hline & & $\mathrm{CaSiO}_{3}$ & $24.4 \mathrm{c}$ & $10.5 \mathrm{a}$ & $110 \mathrm{a}$ & $159 \mathrm{f}$ & $163 a$ & $1,234 \mathrm{~b}$ \\
\hline & & $\mathrm{K}_{2} \mathrm{SiO}_{3}$ & $25.8 \mathrm{~b}$ & 8.9 bc & $107 a b$ & $196 \mathrm{~cd}$ & $155 \mathrm{~b}$ & $1,043 \mathrm{bc}$ \\
\hline & & $\mathrm{Na}_{2} \mathrm{SiO}_{3}$ & $25.6 \mathrm{~b}$ & $9.5 \mathrm{ab}$ & $101 \mathrm{~b}$ & $174 \mathrm{e}$ & $106 \mathrm{e}$ & $1,273 b$ \\
\hline \multirow[t]{8}{*}{ Pink Eye } & Subirrigation & Control & $57.9 \mathrm{~b}$ & $7.4 \mathrm{c}$ & $110 \mathrm{a}$ & $254 a$ & $52 \mathrm{f}$ & 974 ef \\
\hline & & $\mathrm{CaSiO}_{3}$ & 45.9 ef & $6.3 \mathrm{~d}$ & $100 \mathrm{c}$ & $154 \mathrm{f}$ & $49 \mathrm{~g}$ & $1,324 \mathrm{~d}$ \\
\hline & & $\mathrm{K}_{2} \mathrm{SiO}_{3}$ & $50.9 \mathrm{~d}$ & $7.1 \mathrm{~cd}$ & $105 \mathrm{~b}$ & $234 \mathrm{~b}$ & $89 c$ & $1,683 b$ \\
\hline & & $\mathrm{Na}_{2} \mathrm{SiO}_{3}$ & $47.4 \mathrm{e}$ & $6.1 \mathrm{e}$ & $99 \mathrm{~cd}$ & $190 \mathrm{~d}$ & $56 \mathrm{e}$ & $1,463 \mathrm{~cd}$ \\
\hline & Foliar spray & Water & $55.7 \mathrm{bc}$ & $7.7 \mathrm{bc}$ & $101 \mathrm{c}$ & $156 \mathrm{f}$ & $79 d$ & $1,022 \mathrm{e}$ \\
\hline & & $\mathrm{CaSiO}_{3}$ & $52.4 \mathrm{c}$ & $9.7 \mathrm{a}$ & $100 \mathrm{c}$ & 179 e & $114 a$ & $1,709 a b$ \\
\hline & & $\mathrm{K}_{2} \mathrm{SiO}_{3}$ & $61.7 \mathrm{a}$ & $8.4 \mathrm{~b}$ & $99 \mathrm{~cd}$ & $190 \mathrm{~d}$ & $108 \mathrm{~b}$ & $1,789 a$ \\
\hline & & $\mathrm{Na}_{2} \mathrm{SiO}_{3}$ & $61.4 \mathrm{a}$ & $7.2 \mathrm{~cd}$ & $100 \mathrm{c}$ & $206 c$ & $78 \mathrm{~d}$ & $1,534 \mathrm{c}$ \\
\hline \multirow[t]{7}{*}{$\mathrm{F}$ test } & $A$ & & $* * *$ & $* * *$ & $* *$ & NS & $* * *$ & $* * *$ \\
\hline & $\mathrm{B}$ & & $* * *$ & $* * *$ & * & ** & $* * *$ & NS \\
\hline & C & & $* * *$ & * & $* \star *$ & $* *$ & $* * *$ & ** \\
\hline & $A \times B$ & & $* * *$ & NS & $* * *$ & NS & * & NS \\
\hline & $A \times C$ & & $*$ & NS & * & NS & $* *$ & NS \\
\hline & $B \times C$ & & $* * *$ & $* * *$ & $* * *$ & $* * *$ & $* * *$ & NS \\
\hline & $A \times B \times$ & C & $* *$ & NS & * & NS & * & NS \\
\hline
\end{tabular}

${ }^{z}$ Mean separation within columns by Duncan's multiple range test, $P \leq 0.05$

NS, ${ }^{* * * *, * * *}$ Nonsignificant or significant at $P \leq 0.05,0.01,0.001$, respectively. 
Similarly, in this study, addition of Si to the nutrient solution significantly reduced leaf tissue $\mathrm{Na}$ concentrations in both cultivars. However, Si foliar spray increased leaf tissue $\mathrm{Na}$ content of 'Pink Eye' (Table 2).

Cultivar, application method, silicon source, and their interactions had a significant influence in leaf tissue concentrations of $\mathrm{B}, \mathrm{Fe}$, and $\mathrm{Zn}$ (Table 3). Foliar spray of $\mathrm{K}_{2} \mathrm{SiO}_{3}$ or $\mathrm{Na}_{2} \mathrm{SiO}_{3}$ significantly increased leaf tissue $\mathrm{B}$ concentration in 'Pink Eye', while other treatments reduced it in both cultivars as compared with the control. Cultivar, application method, and Si source had a significant effect on leaf tissue $\mathrm{Cu}$ concentration of chrysanthemum cultivars. In both cultivars subirrigational and foliar application of $\mathrm{CaSiO}_{3}$ significantly reduced and increased leaf tissue $\mathrm{Cu}$ concentration, respectively, compared with the control (Table 3). The addition of $\mathrm{Si}$ to the nutrient solution significantly reduced Fe concentration in leaf tissue of 'Lemmon Eye' than 'Pink Eye'. Application method $\mathrm{x}$ Si source interaction on leaf tissue Mn concentration was found to be significant in both cultivars. Similar results have also been reported in alfalfa (Wang and Han, 2007) and gerbera (Kamenidou et al., 2010). The application of $\mathrm{Si}$ significantly reduced $\mathrm{Mn}$ concentration in leaf tissues of both cultivars as compared with the control, whereas leaf tissue $\mathrm{Zn}$ concentration significantly increased with applied $\mathrm{Si}$ except subirrigational supply of $\mathrm{CaSiO}_{3}$. Cultivar and $\mathrm{Si}$ source were significantly affected leaf tissue $\mathrm{Si}$ concentration. Molybdenum blue method confirmed the presence of $\mathrm{Si}$ in leaf tissues of both cultivars, where leaf tissue concentration of Si increased by application of Si (Table 3). Among the three $\mathrm{Si}$ sources, $\mathrm{K}_{2} \mathrm{SiO}_{3}$ was found to be the best for increasing leaf tissue Si concentration of both cultivars. The greatest $\mathrm{Si}$ concentration in leaf tissue was found in 'Lemmon Eye' $\left(1420 \mu \mathrm{g} \cdot \mathrm{g}^{-1}\right)$ and 'Pink Eye' $\left(1683 \mu \mathrm{g} \cdot \mathrm{g}^{-1}\right)$ when $\mathrm{K}_{2} \mathrm{SiO}_{3}$ was applied through a subirrigation system and by foliar spray, respectively. Plants differ greatly in their ability to accumulate Si (Ma and Yamaji, 2006). In our study, significant differences in leaf tissue $\mathrm{Si}$ concentration were found between the two cultivars. A cultivar-specific response to Si supply was also observed in calibrachoa (Mattson and Leatherwood, 2010). The difference in Si accumulation between species has been attributed to differences in the Si uptake ability of the roots (Ma and Yamaji, 2006).

In conclusion, the number, size and fresh and dry weights of chrysanthemum flowers were promoted when the nutrient solution was supplemented with $\mathrm{Si}$, but necrotic lesions developed in leaves. Significant increase in fresh and dry weight of flowers was also obtained with foliar Si spray; therefore, we recommend foliar application of Si for better growth and yield of chrysanthemum cultivars.

\section{Literature Cited}

Bae, M.J., Y.G. Park, and B.R. Jeong. 2010. Effect of silicate fertilizer supplemented to a medium on the growth and development of potted plants. Flower Res. J. 18:50-56.

Cooke, J. and M.R. Leishman. 2011. Silicon concentration and leaf longevity: Is silicon a player in the leaf dry mass spectrum? Funct. Ecol. 25:1181-1188.

Ehret, D.L., J.G. Menzies, and T. Helmer. 2005. Production and quality of greenhouse roses in recirculating nutrient systems. Sci. Hort. 106:103-113.

Epstein, E. 1994. The anomaly of silicon in plant biology. Proc. Natl. Acad. Sci. USA. 91:11-17.

Epstein, E. 1999. Silicon. Ann. Rev. Plant Physiol. Plant Mol. Biol. 50:641-664.

Guo, W., Y.L. Hou, S.G. Wang, and Y.G. Zhu. 2005. Effect of silicate on the growth and arsenate uptake by rice (Oryza sativa L.) seedlings in solution culture. Plant Soil 272:173-181.

Hodson, M.J., P.J. White, A. Mead, and M.R. Broadley. 2005. Phylogenetic variation in the silicon composition of plants. Ann. Bot. 96:1027-1046.

Hwang, S.J., H.M. Park, and B.R. Jeong. 2005. Effects of potassium silicate on the growth of miniature rose 'Pinocchio' grown on rockwool and its cut flower quality. J. Japan. Soc. Hort. Sci. 74:242-247.

Islam, A. and R.C. Saha. 1969. Effect of silicon on the chemical composition of rice plants. Plant Soil 30:446-458.

Jeong, K.J., Y.S. Chon, S.H. Ha, H.K. Kang, and J.G. Yun. 2012. Silicon application on standard chrysanthemum alleviates damages induced by disease and aphid insect. Kor. J. Hort. Sci. Technol. 30:21-26.

Kamenidou, S., T.J. Cavins, and S. Marek. 2009. Evaluation of silicon as a nutritional supplement for greenhouse zinnia production. Sci. Hort. 119:297-301.

Kamenidou, S., T.J. Cavins, and S. Marek. 2008. Silicon supplements affect horticultural traits of greenhouse-produced ornamental sunflowers. HortScience 43:236-239.

Kamenidou, S., T.J. Cavins, and S. Marek. 2010. Silicon supplements affect floricultural quality traits and elemental nutrient concentrations of greenhouse produced gerbera. Sci. Hort. 123: 390-394.

Liang, Y., Q. Shen, Z. Shen, and T. Ma. 1996. Effects of silicon on salinity tolerance of two barley cultivars. J. Plant Nutr. 19:173-183.

Liang, Y., W. Sun, Y.G. Zhu, and P. Christie. 2007. Mechanisms of silicon-mediated alleviation of abiotic stresses in higher plants: A review. Environ. Pollut. 147:422-428.

Liang, Y.C., W.C. Sun, and V. Romheld. 2005. Effects of foliarand root-applied silicon on the enhancement of induced resistance to powdery mildew in Cucumis sativus. Plant Pathol. 54:678-685.

Ma, J.F. and E. Takahashi. 1990. Effect of silicon on the growth and phosphorus uptake of rice. Plant Soil 126:115-119.

Ma, J.F. and N. Yamaji. 2006. Silicon uptake and accumulation in higher plants. Trends Plant Sci. 11:392-397.

Mattson, N.S. and W.R. Leatherwood. 2010. Potassium silicate drenches increased leaf silicon content and affect morphological 
traits of several floricultural crops grown in a peat-based substrate. HortScience 45:43-47.

McAvoy, R.J. and B.B. Bible. 1996. Silica sprays reduce the incidence and severity of bract necrosis in poinsettia. HortScience 31:1146-1149.

Menzies, J., P. Bowen, D. Ehret, and A.D.M. Glass. 1992. Foliar applications of potassium silicate reduce severity of powdery mildew on cucumber, muskmelon, and zucchini squash. J. Am. Soc. Hort. Sci. 117: 902-905.

Miyake, Y. and E. Takahashi. 1978. Silicon deficiency of tomato plant. Soil Sci. Plant Nutr. 24:175-189.

Miyake, Y. and E. Takahashi. 1983. Effect of silicon on the growth of solution-cultured cucumber plant. Soil Sci. Plant Nutr. 29:71-83.

Montpetit, J., J. Vivancos, N. Mitani-Ueno, N. Yamaji, W. RemusBorel, F. Belzile, J.F. Ma, and R.R. Belanger. 2012. Cloning, functional characterization and heterologous expression of TaLsil, a wheat silicon tranporter gene. Plant Mol. Biol. 79: 35-46.

Moon, H.H., M.J. Bae, and B.R. Jeong. 2008. Effect of silicate supplemented medium on rooting of cutting and growth of chrysanthemum. Flower Res. J. 16:107-111.

Parrella, M.P., T.P. Costamagna, and R. Kaspi. 2007. The addition of potassium silicate to the fertilizer mix to suppress Liriomyza leafminers attacking chrysanthemums. Acta Hort. 747:365-370.

Roy, A.C., M.Y. Ali, R.L. Fox, and J.A. Silva. 1971. Influence of calcium silicate on phosphate solubility and availability in Hawaiian Latosols. Proc. Int. Symp. Soil Fert. Eval. New Delhi 1:757-765.

Savvas, D., G. Manos, A. Kotsiras, and S. Souvaliotis. 2002. Effects of silicon and nutrient-induced salinity on yield, flower quality and nutrient uptake of gerbera grown in a closed hydroponic system. J. Appl. Bot. 76:153-158.

Sivanesan, I., M.S. Son, J.P. Lee, and B.R. Jeong. 2010. Effects of silicon on growth of Tagetes patula L. 'Boy Orange' and 'Yellow Boy' seedlings cultured in an environment controlled chamber. Propag. Ornam. Plants 10:136-140.

Sivanesan, I., M.S. Son, J.Y. Song, and B.R. Jeong. 2013. Subirrigational supply of silicon affects the growth of three chrysanthemum cultivars. Hort. Environ. Biotechnol. 54:14-19.

Wang, X.S. and J.G. Han. 2007. Effects of $\mathrm{NaCl}$ and silicon on ion distribution in the roots, shoots and leaves of two alfalfa cultivars with different salt tolerance. Soil Sci. Plant Nutr. 53:278-285.

Wong, Y.C.Y., A. Heitz, and J. DeVille. 1971. Foliar symptoms of silicon deficiency in the sugarcane plant. Proc. $14^{\text {th }}$ Congr. Int. Soc. Sugar Cane Technol. p. 766-776. 